\title{
Gastric Biopsy
}

National Cancer Institute

\section{Source}

National Cancer Institute. Gastric Biopsy. NCI Thesaurus. Code C51685.

Removal of tissue from the stomach for microscopic examination, using an endoscope. 